\title{
Kvaliteta stanovanja u programu javnog najamnog stanovanja: primjer Novog Jelkovca
}

\author{
Gojko Bežovan \\ Sveučilište u Zagrebu, Pravni fakultet, Hrvatska \\ e-mail:gojko.bezovan@pravo.hr
}

\author{
Josip Pandžić \\ Sveučilište u Zagrebu, Pravni fakultet, Hrvatska \\ e-mail: josip.pandzic@pravo.hr
}

SAŽETAK Struktura stambenih statusa u tranzicijskim zemljama rezultat je privatizacije državnog stambenog fonda tijekom 1990-ih i recentnih stambenih politika koje su podržavale vlasništvo nad stanovima. Niz stambenih istraživanja dokazuju da je naglasak na stanovima kao kapitalu doveo do velikog porasta razine vlasništva i cijena stanova te, nakon krize, do pada ulaganja u europskim gradovima. Postoje također dokazi da je stambena potrošnja određenih društvenih skupina snižena, što je dovelo do pogoršanja kvalitete stanovanja, a ponekad čak i gubitka domova. Uporabom postojećih tradicionalnih instrumenata stambene politike teško se je nositi s tim problemima. Program javno najamnih stanova ističe se kao inovacija za podmirivanje hitnih stambenih potreba, odnosno kao priuštivo stanovanje. Program tog tipa u Gradu Zagrebu sačinjen je sa svrhom podmirivanja potreba mladih obitelji s djecom koje nemaju pravo na dodjelu socijalnog stana, a ne mogu si priuštiti stambene kredite za kupnju odgovarajućih stanova. U središnjem dijelu rada prikazani su rezultati ankete provedene među korisnicima programa javnog najamnog stanovanja. Anketnim istraživanjem provedenim na prigodnom uzorku od 270 kućanstava zagrebačkog naselja Novi Jelkovec tijekom prosinca 2014. i siječnja 2015. mjerio se utjecaj modela javno najamnih stanova, kao socijalne inovacije, na kvalitetu stanovanja stanara.

Ključne riječi: tranzicija, javno najamno stanovanje, socijalne inovacije, priuštivo stanovanje, stambene potrebe, Zagreb, Hrvatska. 


\section{Uvod}

Struktura stambenih statusa u postsocijalističkim tranzicijskim državama „ovisna je o prijeđenom putu" (engl. path dependency) i rezultat je privatizacijske podjele (engl. giveaway privatization) stambenog fonda u državnom vlasništvu s početka 1990-ih te recentnih stambenih politika koje su podržavale stambeno vlasništvo, ne obraćajući gotovo nikakvu pozornost na socijalno najamno stanovanje. ${ }^{1}$ Stalni izazovi u državama Srednje, Istočne i Jugoistočne Europe i dalje su vezani za polariziranu strukturu stambenih statusa, manjak ulaganja u socijalno stanovanje, neučinkovite subvencije i rastuću nepriuštivost stanovanja (Tsenkova, 2003.; Hegedüs, Teller i Lux, 2013.; Stephens, Lux i Sunega, 2015.; Lux, 2019.). U tranzicijskom razdoblju dohodovne su se nejednakosti povećale, nezaposlenost je relativno visoka, a nesigurnost je postala dio svakodnevice (Hegedüs, 2013.; Hegedüs, Horváth i Somogyi, 2017.; Lux, 2019.). Značajna potpora kućevlasnicima u obliku kreditno-hipotekarnih subvencija i programa stambene štednje, prema empirijskim dokazima prethodno referiranih autora, često je imala regresivni redistributivni učinak. U okolnostima neulaganja u socijalne stanove privatni najamni stanovi postali su jedno od ključnih područja stambene politike (Hegedüs, Lux i Horváth, 2018.).

Na primjeru Češke empirijski je utvrđeno, putem analize odgovora iz anketnog istraživanja preferencija mogućeg ponašanja u slučaju iznenadnog gubitka zaposlenja, da vlasništvo nad stanovima ima ulogu prepreke migracijama radne snage te da se može smatrati jednim od izvora strukturne nezaposlenosti (Lux i Sunega, 2012.). Temeljem komparativnih uvida iz češkog i mađarskog slučaja, u postsocijalističkim državama uravnoteženija struktura stambenih statusa Češke smatra se poželjnijom opcijom u odnosu na dominantno kućevlasničku strukturu stambenih statusa u Mađarskoj (Hegedüs, Lux i Sunega, 2011.). Opsežna studija socijalnog stanovanja u tranzicijskim zemljama (Hegedüs, Lux i Teller, 2013.) pokazala je da su vlade u postsocijalističkim državama pod utjecajem privatnih interesa povezanih $s$ bankama, poduzetnicima i drugim dionicima. U takvom je okruženju teško utjecati na priuštivost stanovanja (engl. affordable housing) kao ključnu činjenicu koja dominira stambenom politikom u tranzicijskim zemljama. Pomaganje siromašnima, u okolnostima u kojima njihove službene izjave o prihodima i imovini (engl. means test) nisu pouzdane, svim progra-

1 Prije i u vrijeme provođenja istraživanja na čijim se rezultatima ovaj rad temelji prvi autor bio je član Nadzornog odbora Zagrebačkog Holdinga zaduženog za upravljanje ovim programom i stambenim naseljem Novi Jelkovec, a na toj se funkciji nalazi i u vrijeme pisanja ovog rada. Provedba terenskog dijela istraživanja financirana je iz sredstava Potpore znanstvenim i umjetničkim istraživanjima Sveučilišta u Zagrebu za 2014. godinu na temu „Socijalna inovacija javno najamnih stanova kao odgovor na stambenu krizu" te sredstava OIKONET - Erasmus Networks projekta sufinanciranog od Izvršne agencije za obrazovanje, audiovizualnu politiku i kulturu Europske unije [539369-LLP-1-2013-ES-ERASMUSENW]. Ovo je istraživanje izvorno koncipirano i započeto u sklopu potonjeg projekta. Konačno, zahvale pripadaju Jeleni Ogresti na pomoći pri analizi podataka i korisnim sugestijama, čime je rukopis uvelike poboljšan. 
mima provjere sredstava prijeti rizikom zloporabe, što se u konačnici odražava u financijskim iznosima pomoći. U takvoj situaciji nije politički popularno pružati takav oblik pomoći siromašnima (Lux i Sunega, 2013.).

Rezultati komparativnog istraživanja u 20 europskih gradova upućuju na činjenicu da je naglasak na stanovima kao kapitalu doveo do velikog rasta razina vlasništva i cijena stanova te, nakon početka globalne financijske krize, do pada stambenih ulaganja u tim gradovima. ${ }^{2}$ Stambena potrošnja pojedinih skupina neodrživa je za njihove kućne proračune, a to je dovelo do pogoršanja kvalitete stanovanja, ponekad i do gubitka domova. Povećani broj kućanstava s niskim prihodima i prekarni radnici suočavaju se $s$ preprekama kupnje vlastitih stanova, više no ikad zbog konteksta ograničenih ulaganja u novo socijalno najamno stanovanje i privatizacije dijela tog fonda (Costa, Bežovan, Plavarini i Brandsen, 2014.: 183-184). Rezultati spomenutog istraživanja također su pokazali da učinci krize na različite skupine odražavaju razlike svojstvene tipologiji „režima socijalnih država“ (engl. welfare regimes) (Esping-Andersen, 1990.; Ferrera, 1996.; Fenger, 2007.). Provedene mjere stambenog zbrinjavanja u gradovima iz istraživanja imaju tek ograničene učinke u slučaju postojanja velike neusklađenosti između ponude i potražnje stanova. Problemi su posebno izraženi u mediteranskim i gradovima tranzicijskog režima (Poljska i Hrvatska) te se je teško s njima nositi postojećim instrumentima stambene politike, kao što su subvencioniranje troškova stanovanja, porezne olakšice za kupnju stana, ili konačno gradnjom naselja socijalnog stanovanja, kao u poratnom razdoblju s polovine prošlog stoljeća ${ }^{3}$. Zbog toga je potrebno usredotočiti se na socijalne inovacije, koristeći se poveznicama stanovanja i drugih područja socijalne politike. To zahtijeva manji naglasak na financijska ulaganja, a veći na stanovanje kao polugu za socijalna ulaganja. ${ }^{4}$ Po iskustvima razvijenih gradova moglo bi se očekivati da će povećani pritisak na ranjive skupine, osobito mlade, pridonijeti njihovoj samoorganizaciji i snažnijem poticanju lokalnih socijalnih inovacija u području stanovanja, odnosno stambenih inovacija. ${ }^{5}$

Ovaj rad temelji se na rezultatima analize socijalne inovacije javnog najamnog stanovanja u glavnom gradu Hrvatske, Zagrebu. Dio analize odnosio se na stambenu situaciju u okviru stambenih inovacija. Koncept inovacije bavi se položajem korisni-

\footnotetext{
${ }^{2}$ Više o EU FP7 projektu u sklopu kojeg je istraživanje izvršeno vidjeti na: http://www.wilcoproject.eu/.

3 Posljednja mjera bila je usmjerena hitnom zbrinjavanju stanovništva koje je uslijed ratnih razaranja ostalo bez krova nad glavom kao i deagrarizirane populacije novostvorenih industrijskih radnika te njihovih obitelji porijeklom iz ruralnih sredina.

${ }^{4}$ Koncept socijalnih ulaganja nova je paradigma u socijalnoj politici usmjerena na prevenciju novih socijalnih rizika. Vidi: Hemerijck, 2017. Paket socijalnih ulaganja EU-a snažno zagovora taj pristup. Vidi: Europska komisija, 2013.

${ }^{5}$ U okviru MOBA Housing network, što se može kvalificirati kao samoorganizacija građana, provodi se i pilot projekt u Križevcima, vidjeti: https://moba.coop/pilot-projects
} 
ka, unutarnjom organizacijom i načinom rada te interakcijama s lokalnim socijalnim sustavom. ${ }^{6} \mathrm{U}$ središnjem dijelu rada prikazani su rezultati anketnog istraživanja provedenog na prigodnom uzorku kućanstava u javno najamnom stambenom statusu. Empirijskim dokumentiranjem dodane vrijednosti programa stambenog zbrinjavanja uočilo se kako je stambena inovacija u određenim segmentima poboljšala kvalitetu stanovanja najmoprimaca. Istraživanje je pružilo dokaze o održivosti tog programa kao socijalnog ulaganja s potencijalom za ponovnu implementaciju. Također, iz empirijskih su dokaza bila razvidna određena ograničenja te socijalne inovacije, no to se u osnovi odnosilo na ponudu veličine stambenih jedinica najmoprimcima i njezinim odnosom s priuštivošću stanovanja.

\section{Stambeni problemi u kontekstu socijalnih inovacija}

Stambena kriza u postsocijalističkim državama mnogo je puta dokumentirana upućivanjem na različite teme (Tsenkova, 2009.; Hegedus, 2013.; Costa, Bežovan, Plavarini i Brandsen, 2014.; Hegedüs, Lux i Horváth, 2018.) i probleme koji se odnose na kvalitativni (neadekvatno stanovanje) i kvantitativni (nedostatak pristupačnih stambenih jedinica) stambeni deficit gradova. Nakon završetka procesa privatizacije javnog stambenog fonda, visok udio vlasništva u strukturi stambenih statusa podrazumijevao je velik prijenos bogatstva i nastanak društava s istim obilježjima, a koje se upravo stoga u literaturi naziva „superkućevlasničkim društvima“ (Elsinga i Mandič, 2010.; Lux, 2019.). Privatizacija stanova u državnom vlasnišsvu u postsocijalističkim tranzicijskim državama također je proizvela regresivni socijalni učinak: imućna kućanstva materijalno su profitirala, dok ona s niskim primanjima nisu mogla otkupiti svoje stanove po sniženoj cijeni, te su stoga ostala „zarobljena“ u socijalnom najamnom statusu. Sektor socijalnog najamnog stanovanja postao je rezidualan i ograničen na stambeno zbrinjavanje najranjivijih društvenih skupina, dok je vlasništvo nad stanovima, podržavano novim mjerama stambene politike, postalo dominantan stambeni status (Hegedüs, 2013.) i na neki način društvena norma (Lux, 2019.). Mnogi problemi vezani uz stambenu krizu izravno se odnose na pripadnike mlađih generacija koji žive s obiteljima, a oni ujedno predstavljaju ključni razvojni čimbenik u budućnosti država pred kojima stoji izazov demografskog starenja i iseljavanja (Bežovan, 2019.). Postsocijalistička „superkućevlasnička društva“ ne obilježavaju samo strukture stambenih statusa već i stambene politike orijentirane na vlasništvo nad stambenim nekretninama kada je riječ o statusima i opskrbi. Za ostale statuse mogućnosti podmirivanja stambenih potreba nisu povoljne u kućevlasničkoj strukturi stambene opskrbe (Ball, 1983.) kojom dominiraju tržišni odnosi. U tom smislu postoji značajna potreba za inovacijama.

${ }^{6}$ Lokalni socijalni sustavi ovdje se najopćenitije definiraju kao „različiti aranžmani formalnih i neformalnih aktera, javnih ili onih koji to nisu, uključenih u oblikovanje i implementaciju socijalnih politika“ (Andreotti, Mingione i Polizzi, 2012: 1926). 
Stanovanje je prepoznato kao kritičan problem u posljednjih 25 godina u Zagrebu, glavnom gradu Hrvatske (Bežovan, 2005.; 2012.). Stanovanje je u Hrvatskoj, uz nekoliko vrijednih iznimaka kao što su istraživanja kvalitete života (Svirčić Gotovac, 2006.; Svirčić Gotovac i Zlatar, 2015.), tranzicijskog tržišta nekretnina (Tica, 2002.) i priuštivosti cijena stanova (Vizek, 2009.; Tkalec, Vizek i Žilić, 2018.), nedovoljno istraženo područje.

U Hrvatskoj je 1991. godine javni stambeni fond („društveni stanovi“) činio ukupno 25,1\%, a u Zagrebu 45,4\% stambenog fonda ${ }^{7}$, dok je 2011. u Zagrebu riječ o 85,6\% kućanstava u vlasničkom statusu, a u Hrvatskoj 88,9\% (DZS, 1991., 2011.).

Podaci iz popisa stanovništva 2011. godine pokazuju impresivno povećanje stambenog fonda, iz čega je također razvidna koncentracija akumulacije bogatstva ulaganjem u stambeno vlasništvo. U deset godina stambeni se fond u Zagrebu povećao za $22 \%$, a broj stanova značajno je premašio broj kućanstava. $S$ obzirom na to da je trgovanje stambenim nekretninama prije početka financijske krize predstavljalo jedno od najprofitabilnijih područja poslovanja, povećana ulaganja uglavnom su bila špekulativnog karaktera. ${ }^{8}$ Obitelji zaduživane tijekom 2000-ih stambenim kreditima preračunatim u švicarske franke s vremenom su zapale u ozbiljne financijske probleme, što je u konačnici postao i ozbiljan problem političke naravi jer su pogođena kućanstva stvorila društveni pokret za zaštitu svojih prava. ${ }^{9}$

Stambena politika, kao javnopolitički prostor pogodan za socijalne inovacije, decentralizirana je, rascjepkana i prepuštena na volju lokalnim političarima. Iako je stambena kriza evidentna i prethodno empirijski dokumentirana u Zagrebu (Bežovan, 2012.), ugrožene društvene skupine (mlade obitelji, samačka kućanstva, unutarnji migranti, starije osobe, razvedeni parovi) nisu organizirane u organizacijama civilnog društva orijentiranima na pomoć u stambenoj opskrbi. ${ }^{10}$ Nadalje, ne postoje zagovaračke or-

${ }^{7}$ Na nacionalnoj razini udio javnih/društvenih stambenih jedinica iznosio je 25\%.

8 Usporediti: UNECE, 2009.

${ }^{9}$ Važno je napomenuti da je, osim Udruge Franak, društveni pokret pod nazivom Živi zid - prvenstveno usmjeren na borbu protiv deložacija - s vremenom postao organiziran kao (populistička) politička stranka istog imena. To se može objasniti kao nenamjeravana posljedica financijskih, a time i učinaka stambene krize. Te su udruge izvršile pritisak na vladu da se 2017. godine donese „europski“ Zakon o stambenom potrošačkom kreditiranju. U rujnu 2019. Vrhovni je sud presudio da su banke povrijedile kolektivne interese i prava potrošača korisnika kredita sklapanjem ugovora o kreditu koristeći u njima nepoštene i ništetne ugovorne odredbe - ugovaranjem valute uz koju je vezana glavnica švicarski franak (valutna klauzula), a da se o tome nije pojedinačno pregovaralo. Vidi detaljnije na: http://www.poslovni. hr/trzista/vrhovni-sud-donio-presudu-banke-povrijedile-prava-korisnika-kredita-u-svicarcima-357516.

10 Usporedi pregled civilnih inicijativa samoorganiziranog, kolaborativnog i zadružnog stanovanja iz deset država (Austrija, Australija, Engleska, Norveška, Švedska, SAD, Francuska, Španjolska, Belgija i Italija) u: Mullins i Moore, 2018. 
ganizacije koje bi se bavile problemom podmirivanja hitnih stambenih potreba i potrebom za priuštivim najamnim stanovanjem. U novije vrijeme određene građanske organizacije koje se bave borbom protiv nasilja u obitelji utjecale su na podzakonske propise, odnosno kriterije temeljem kojih se ostvaruje pravo na stanovanje u socijalnim stanovima, pa se tako sada žrtve obiteljskog nasilja nalaze na listi prioriteta. Međutim, empirijski evidentiran nedostatak priuštivih stanova (Tkalec, Vizek i Žilić, 2018.) jest ključni problem, a tematski je prisutan i u vrlo rijetkim javnim raspravama, unatoč činjenici da ih se većina održava na internetskim forumima.

Ranija procjena stambenih potreba u Gradu Zagrebu (Bežovan, 2012.; za stanovanje kao faktor kvalitete života vidi u: Svirčić Gotovac i Zlatar, 2015.) ukazala je na ranjivost mladih obitelji i samaca. Ta populacija nije u mogućnosti stambeno se zadužiti, izložena je nekontroliranom privatnom najamnom tržištu, na kojem si ne može priuštiti pristojno stanovanje ili je naposljetku prisiljena dijeliti stambeni prostor sa širom obitelji. Nepriuštivost pristojnog stanovanja negativno utječe na demografski razvoj, a okidač je i za odluke mladih o iseljavanju iz zemlje (Bežovan, 2019.).

Javno raspravljeni projekt javno-najamnih stanova s dokumentiranim problemom nedostatka priuštivog najamnog stanovanja za mlade generacije, te uz potrebnu razinu političke volje i s podrškom stručnjaka izvan gradske uprave uključujući i same administrativne kapacitete nadležnih gradskih službi, bili su pokretačka snaga nastanka specifične stambene inovacije usmjerene prema podmirivanju evidentiranih socijalnih stambenih potreba. ${ }^{11}$

\section{Koncept socijalnih inovacija u području stanovanja}

Socijalno inoviranje praksom je vođeno područje; ono je kontekstualno i kao takvo se razvilo s nedostatno definiranim granicama, značenjima i definicijama. Socijalne inovacije mogu se definirati kao nove ideje (proizvodi, usluge i modeli) koje istovremeno podmiruju socijalne potrebe (učinkovitije od alternativa) i stvaraju nove društvene odnose ili suradnje. Drugim riječima, to su inovacije koje nisu samo dobre za društvo u cjelini, već i povećavaju sposobnost društva da djeluje (BEPA, 2010.). One su neka vrsta ideja, pretvorenih u praktične pristupe koji su novi u kontekstu u kojem se pojavljuju. Phills, Deiglmeier i Miller (2008.: 36) definiraju socijalnu inovaciju kao „novo rješenje za socijalni problem koje je učinkovitije, djelotvornije, održivije ili pravednije od postojećih rješenja i zbog kojeg stvorena vrijednost prije svega pritječe društvu kao cjelini prije nego pojedincima“. Socijalna inovacija može biti proizvod, proizvodni proces ili tehnologija (slično inovaciji općenito), ali može biti i načelo, ideja, dio zakonodavstva, društveni pokret, intervencija ili neka kombinacija spomenutog.

11 Javna rasprava prilikom donošenja Odluke o najmu javno najamnih stanova provedena je na mrežnoj stranici Grada Zagreba. 
Rješenja trebaju biti usredotočena na korisnike i biti sačinjena s njima, po mogućnosti od njih samih, i nikada bez njih. Socijalne inovacije smatraju se jednim od ključnih elemenata za podupiranje održivog, pametnog i uključivog rasta. Nadalje, ključni izazovi uspostave socijalnih inovacija njihova su održivost, financiranje i prepoznavanje (Bežovan, Matančević i Baturina, 2016.). Socijalne inovacije trebale bi pružiti stabilnu strukturu financiranja kako bi se inicijative pokrenule i razvile. Konačno, trebaju biti organizacijski snalažljive i oslanjati se na različite dionike.

U središtu se čitavog „područja nepodmirenih socijalnih potreba“ nalazi upravo stanovanje zbog povećanja nepristupačnosti i nepriuštivosti stanovanja u najamnom ili stambeno-kreditnom smislu tijekom proteklih dvaju desetljeća i to za sve veći broj pojedinaca i kućanstava (Garcia i Haddock, 2016.: 393). Stambene inovacije društvene su inovacije u području stanovanja (Czischke, 2013.) i mogu se definirati parafraziranjem definicije socijalnih inovacija (BEPA, 2010.: 24). U tom smislu stambene su inovacije „nove ideje (proizvodi, usluge i modeli) koje istovremeno podmiruju stambene potrebe (učinkovitije od alternativa) i stvaraju nove stambene odnose ili suradnju" ${ }^{12}$ Stambene inovacije proizvode različite vrste opipljivih usluga, vidljivo služeći podmirivanju ranije politički nepriznatih socijalnih potreba, gdje umjesto socijalnih prava postoje ugovorni odnosi s potencijalom razvijanja nove kulture odgovornog najmoprimstva. Socijalne inovacije u stanovanju mogu biti vođene od vlasti (lokalne i nacionalne), civilnog društva (tj. neprofitnih stambenih organizacija) i poslovnog sektora, ali su suradnja i koordinacija među relevantnim dionicima na temeljima „dobre (urbane) vladavine“ (Kearns i Paddison, 2000.; Elliot, 2006.) ključni čimbenici za uspjeh bilo koje konkretne inovacije.

Slijedeći jedinstvenu studiju u ovom području (Czischke, 2013.), može se navesti nekoliko tematskih potpodručja stambenih inovacija u Europi, iako je socijalna inovativnost u stanovanju dobila malo pozornosti u javnoj ili akademskoj raspravi, pri čemu jedinu iznimku čini problem beskućništva (primjerice program „Stanovanje prvo“). Neka od potpodručja su (Czischke, 2013.: 9-14):

(1) demografske promjene u stambenom zbrinjavanju - pružanje priuštivog smještaja i skrbi za starije osobe u zadružnom stambenom aranžmanu, na što imaju pravo sve starije osobe u gradu (SeniorForum u Švedskoj);

12 Korisno je uočiti razliku između socijalnih inovacija i stambenih inovacija kao podtipa s jedne strane te urbanih i/ili lokalnih inovacija s druge strane. Prve predstavljaju inovacije temeljene na određenom cilju ili području stručnosti, dok urbane i lokalne inovacije označavaju socioprostorni kontekst u kojem se pojavljuju ili se mogu nalaziti. Međutim, istraživanja o „socijalnim inovacijama u urbanom kontekstu“ novijeg su datuma, ali uspješno tematiziraju različite usluge u europskim gradovima. Vidi više u: Brandsen, Cattacin, Evers i Zimmer, 2016. Također pogledati literaturu o lokalnim sustavima socijalne skrbi u Europi: Ranci, Brandsen i Sabatinelli, 2014. 
(2) korištenje europskih mreža za inoviranje - razvoj i primjena europskog standarda koji će tvrtke za socijalno stanovanje koristiti pri izvještavanju i upravljanju društveno odgovornim poslovanjem (EURHO-GR u Grenobleu, Orebru, Darmstadtu, Bresci);

(3) racionalizacija ulaganja u zajednicu - stvaranje zaklade za bavljanje socijalnim problemima (Batigère zaklada u Francuskoj);

(4) novi načini pomaganja ugroženim skupinama u stambenom zbrinjavanju - potpora obiteljima koje su u riziku gubljenja vlastitih domova zbog neplaćenih hipotekarnih kredita (medijacijski program vezan uz hipotekarna dugovanja u Zaragozi u Španjolskoj).

Kako bi se adekvatno shvatio koncept stambene inovacije u postsocijalističkom kontekstu, potrebno je isprva istaknuti razlikovanje izuma i inovacije. Socijalno i javno najamno stanovanje u različitim oblicima diljem Europe pojavilo se kao novi politički instrument ili izum, uglavnom nakon velikih ratova 20. stoljeća, kako bi se podmirile hitne stambene potrebe velikog broja građana (Harloe, 1995.). Od tada su konvencionalni načini i pristupi stambenim problemima, kao što je masovno najamno stanovanje razvijeno diljem Europe nakon Drugog svjetskog rata, postali politički zastarjeli, socijalno neučinkoviti i ekonomski kontraproduktivni čak i prije promjene javnih politika prema politici štednje, odnosno rezanja potrošnje (Blyth, 2013.), koja još uvijek prevladava u mnogim aspektima kao političko-ekonomska orijentacija za države članice EU-a, posebice u pogledu stambene i socijalne (proračunske) potrošnje.

Danas se, iako se socijalni ili javni programi stambenog zbrinjavanja smatraju poznatom komponentom socijalne države u zemljama u kojima postoji tradicija stambene politike, taj instrument pojavljuje kao novi instrument stambene politike ili inovacija u kontekstu u kojem takvi programi ne postoje. Drugim riječima, to nije izum, već relativno poznata ideja koja se provodi u novom kontekstu (koji ne poznaje takav program) sa svrhom podmirivanja stambenih potreba skupina koje su bile ograničene društvenim okolnostima izvan njihovog izravnog utjecaja i izbora (nezaposlenost, visoke cijene stanova, kamatne stope na kredite u sustavu komercijalnog bankarstva i druge).

\section{Javno najamno stanovanje kao inovacija}

U prigradskom zagrebačkom naselju Novi Jelkovec, sagrađenom u okviru Zagrebačkog modela stanogradnje, ostvaren je program javno najamnog stanovanja. ${ }^{13}$ Gradnja stanova započinje 2006., a prva se kućanstva useljavaju 2009. godine. U naselju ukupno postoji 2713 stambenih jedinica, uključujući drugu socijalnu infrastrukturu. To je prvo relativno veliko stambeno naselje u gradu koje je planirano sa svom potrebnom

$13 \mathrm{Na}$ toj lokaciji pripremao se vladin program POS-a, međutim Grad Zagreb je otkupio zemljišre s projektom naselja od vlade i to je postao prvi projekt Zagrebačkog modela stanogradnje. 
infrastrukturom nakon dugo vremena. Program gradnje socijalne infrastrukture usporio se tijekom krize. U početku je ozbiljan problem predstavljala povezanost u smislu javnog prijevoza, a poslije je to poboljšano uvođenjem dodatnih autobusnih linija. U sklopu Zagrebačkog modela stanogradnje Grad Zagreb je implementirao u tom naselju koncept socijalnog miksa, pri čemu po jedna trećina stanova otpada na različite stambene statuse: socijalno najamno stanovanje, javno najamno stanovanje i stanovi za kontrolirano tržište. U svakoj od kategorija izvršen je odabir ciljanih skupina. Kontrolirano tržište bilo je namijenjeno mladim obiteljima s djecom u svrhu kupnje prvog stana uz subvenciju cijena. Taj je program utjecao na snižavanje cijena na stambenom tržištu u Zagrebu. Ciljane skupine za socijalni najam bile su kućanstva s liste čekanja nižeg socioekonomskog statusa, dok je javno najamno stanovanje namijenjeno uglavnom kućanstvima nižeg srednjeg i srednjeg socioekonomskog statusa. Odabir javno najamnih najmoprimaca obavljen je javnim natječajem.

U postsocijalističkoj državi kao što je Hrvatska zagrebački program javnog najamnog stanovanja predstavlja stambenu inovaciju. Na sudjelovanje u programu imaju pravo mlada kućanstva, do 35 godina starosti, s više djece, a koja su podstanari na privatnom tržištu najma ili žive zajedno sa širom obitelji, ali u nepovoljnim stambenim uvjetima.

Primjerice, u slučaju podstanarskog statusa u pravilu su kućanstva u mogućnosti unajmiti male stanove, često loše kvalitete, za relativno visoke cijene. Za stan od $30-40 \mathrm{~m}^{2}$ plaća se najam od približno 240 EUR mjesečno, a za stan od $80 \mathrm{~m}^{2}$ u ovom programu 204 EUR. ${ }^{14}$ Budući da u podstanarskom statusu kućanstva najčešće ne potpisuju ugovor o najmu, ona ne mogu prijaviti svoje stalno prebivalište. Stalni boravak na određenoj adresi preduvjet je, primjerice, za upis djece u dječji vrtić. Kućanstva s takvim nestabilnim statusom $u$ riziku su od stalnog seljenja i, ukoliko nisu u mogućnosti pronaći priuštive stanove u susjedstvu, utoliko su prisiljeni mijenjati školu za djecu. $\mathrm{U}$ različitim aspektima spomenuta iskustva u podmirivanju stambenih potreba dovela su te obitelji u položaj da postanu prototip socijalno isključenih osoba uslijed nemogućnosti ostvarivanja socijalnih prava, kao što je sudjelovanje djece u programima predškolskog odgoja i obrazovanja. Mlade obitelji koje žive s roditeljima ili s drugim članovima obitelji, a često se radi o trima generacijama obitelji koje žive zajedno dijeleći prostor u malim stanovima, u riziku su od sukoba u takvim velikim kućanstvima. U takvim slučajevima prenaseljenih stanova članovi obitelji pate od nedostatka prostora i potrebne privatnosti.

${ }^{14}$ Zbog posljedica ekonomske krize Grad Zagreb je snižavao visinu najamnina. Više o kriterijima dodjele i prilagodbe ove inovacije kriznom vremenu vidjeti u: Odluka o najmu javno najamnih stanova (Službeni glasnik Grada Zagreba 7/09, 22/09, i 26/14) te Zaključak o visini najamnine za javno najamne stanove (Službeni glasnik Grada Zagreba, 1/14. Visina najamnine za javno najamne stanove utvrđuje se u mjesečnom iznosu, u kunskoj protuvrijednosti, i to: za stanove do $60 \mathrm{~m} 2 \mathrm{u}$ visini 64,00 eura $+1,60 \mathrm{eura} / \mathrm{m} 2$; za stanove od $60,00 \mathrm{~m} 2-100 \mathrm{~m} 2 \mathrm{u}$ visini 92 eura $+1,40$ eura/m2; za stanove veće od 100,00 $\mathrm{m} 2 \mathrm{u}$ visini 108 eura $+1,20$ eura/m2. Najamnina za stan od $80 \mathrm{~m} 2$ iznosi 1510 kuna. 
U okviru ovog programa korisnici, odabrani putem javnog poziva, dobivaju ugovor na pet godina, s mogućnošću produljenja. Oni također plaćaju relativno niže najamnine od onih na privatnom tržištu najma i stanuju u vrlo pristojnim, dovoljno velikim stanovima u novosagrađenom naselju. Pri podmirivanju potreba takvih korisnika vidljivo je kako stanovanje, kao temeljna odrednica dobrobiti ljudi, ima ključnu ulogu u jačanju socijalne integracije i kohezije (European Commission, 2010.). Pristojno stanovanje može osigurati sudjelovanje ljudi u životu zajednice.

Unutarnja organizacija ovog inovativnog programa bila je dijelom odgovornosti lokalne uprave i lokalne gradske tvrtke odgovorne za upravljanje stambenim fondom. Proces dobivanja statusa stanara u programu javnog najamnog stanovanja transparentan je i na natječaj se mogu prijaviti sve obitelji čiji statusi odgovaraju natječajnim kriterijima. Najmoprimci sklapaju ugovor o najmu i uplaćuju predujam kao jamstvo za redovito plaćanje najamnina i održavanje stana na odgovarajući način. Takav predujam, kao mjera osiguranja, predstavlja neku vrstu nove prakse u lokalnom socijalnom sustavu. ${ }^{15}$ Jedan važan kriterij za podnositelje zahtjeva koji ispunjavaju ranije navedene uvjete jest da kućanstvo treba pružiti dokaze o iznosu dohotka po članovima kućanstva. Razina dohotka po kućanstvu treba biti najmanje na razini od 30\% prosječnog dohotka u Gradu Zagrebu. Navedeni kriteriji daju prednost obiteljima u kojima su oba roditelja zaposlena i zapravo jamče redovito plaćanje najamnine.

Program javno najamnog stanovanja proizveo je izvjesnu interakciju mladih obitelji s djecom s lokalnim socijalnim sustavom, unoseći tako nov duh u lokalne politike, gdje su se službenici uglavnom bavili siromašnom kao i općenito ranjivom populacijom. Javni najmoprimci, prema iskazima gradskih službenika, prepoznaju se kao odgovorniji građani u odnosu na najmoprimce u socijalnim stanovima. Redovito plaćaju najamnine i više se brinu o održavanju stana. Ova socijalna inovacija nosi i potencijal socijalnog ulaganja $s$ vrlo održivim povratom u bliskoj budućnosti. Program javno najamnog stanovanja prvi je slučaj inoviranja fragmentiranog stambenog sektora u Hrvatskoj, dok je također očigledna nova uloga lokalnih vlasti u podmirivanju vidljivih socijalnih potreba ranjivog stanovništva. Iz rezultata istraživanja u drugim tranzicijskim zemljama razvidno je da se na izazove ustanovljenja učinkovitog i održivog sustava socijalnog i javnog najma teško odgovara te da se stambene jedinice takvih projekata zbog nasljedstva zamke privatizacijske podjele naknadno privatiziraju (Hegedüs, Teller i Lux, 2013.; Lux, 2019.). Ovaj je program koncepcijski dopunio lokalni socijalni sustav te ga učinio suvremenijim i osjetljivijim na socijalne rizike ${ }^{16}$, zbog čega

\footnotetext{
15 Najmoprimci u programu socijalnog stanovanja, prema informacijama iz nadležnih službi, vrlo često nisu spremni platiti najamninu i druge troškove vezane za stanovanje (struja, plin, grijanje, voda, komunalna naknada).

16

Ovdje se tvrdi kako u okolnostima izražene stambene krize dugotrajno podstanarstvo na neuređenom tržištu privatnog najma posjeduje obilježja stambene isključenosti, a nepriuštivost pristojnog stanovanja smatra se socijalnim rizikom.
} 
naposljetku može biti smatran prekretnicom u procesu reforme lokalnog socijalnog sustava kroz pružanje većeg prostora za socijalne inovacije i eksperimentiranje.

\section{Metoda istraživanja}

Anketnim istraživanjem provedenim na prigodnom uzorku od 270 kućanstava zagrebačkog naselja Novi Jelkovec tijekom prosinca 2014. i siječnja 2015. godine željelo se izmjeriti utjecaj modela javno najamnih stanova, kao socijalne inovacije, na kvalitetu stanovanja stanara. Drugim riječima, željelo se istražiti načine na koje je novi stambeni status unaprijedio kvalitetu života stanara, pa se stoga testirala glavna hipoteza (hipoteza 1) koja glasi: Najmoprimci u programu javno najamnog stanovanja zadovoljniji su kvalitetom stanovanja u sadašnjem stambenom statusu u odnosu na prethodni.

Od ukupno 530 kućanstava iz gradskog popisa 102 su odbila sudjelovati u istraživanju, dok je 158 anketnih upitnika ostalo nerealizirano iz različitih razloga (trenutno odsustvo, promjena stambenog statusa i sl.). Upitnik je uključivao pitanja o prijašnjem stambenom statusu kućanstva, veličini stana, broju soba, cijenama najma, režijskim troškovima (grijanje, struja i sl.), zadovoljstvu uvjetima stanovanja, kvaliteti susjedstva i druga. ${ }^{17}$ Anketa je provedena tehnikom licem u lice s odabranim članovima kućanstva unutar njihovih stanova. U anketiranju su sudjelovali profesionalni anketari i doktorandi Poslijediplomskog doktorskog studija Socijalne politike Pravnog fakulteta Sveučilišta u Zagrebu. Anketari su vodili dodatne bilješke tijekom anketiranja u svrhu potpunijeg razumijevanja nalaza istraživanja. $U$ to su vrijeme obavljena i dva neformalna informativna intervjua sa službenim osobama u Gradu Zagrebu koje su bile odgovorne za upravljanje tim stanovima, a od njih su dobiveni podaci o strukturi stanova koji su natječajem dani u najam, o najmoprimcima u tim stanovima te o izazovima upravljanja tim programom.

\section{Prikaz rezultata istraživanja}

Od 270 anketiranih kućanstava više od polovine $(64,8 \%)$ bili su podstanari, dok ih je 6,3\% živjelo u podstanarstvu s roditeljima ili prijateljima. Više od jedne petine $(21,9 \%)$ ispitanika živjelo je kod roditelja. Kao što je prethodno spomenuto, ciljana populacija za ovaj program bili su podstanari i pojedinci koji su živjeli s roditeljima. Sukladno tome implementacija projekta bila je uspješna, obuhvativši čak 93\% stanara koji spadaju u ciljanu skupinu. Ranjivost spomenutih ciljanih skupina na stambenom tržištu dokumentirana je u drugim istraživanjima (Bežovan, 2012.).

17 U ovom radu analiziran je ograničeni broj varijabli iz istraživanja. 
Nešto manje od polovine obitelji (43\%) živjelo je u stanovima u stambenim zgradama prije ulaska u ovaj program. Usporedbom pravnih i stambenih statusa kućanstava prije ulaska u program, dobiveni podaci pokazuju da je više od polovine $(54,3 \%)$ bivših podstanara živjelo u stanovima u stambenim zgradama (tablica 1), što znači da imaju iskustvo življenja u urbanim sredinama te posjeduju vještine dijeljenja prostora u kolektivnom stanovanju. Privatno iznajmljivanje stana (20,6\%) može se smatrati neovisnijim načinom života, dok se život u obiteljskoj kući $(14,3 \%)$ i s roditeljima u stanu u stambenoj zgradi (4,6\%), ukupno $18,9 \%$, može smatrati krajnje nepovoljnim. ${ }^{18}$

Tablica 1.

Usporedba pravnih i stambenih statusa prije ulaska u program

\begin{tabular}{|c|c|c|c|c|c|c|c|}
\hline \multirow[b]{2}{*}{$\begin{array}{l}\text { Stambeni status prije } \\
\text { useljenja }\end{array}$} & \multicolumn{7}{|c|}{ Pravni status prije useljenja (\%) } \\
\hline & $\begin{array}{l}\stackrel{\text {. }}{\bar{n}} \\
\stackrel{\tilde{m}}{>}\end{array}$ & 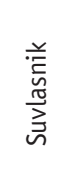 & 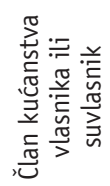 & 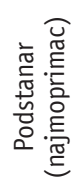 & 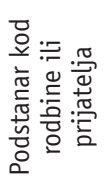 & 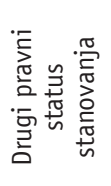 & $\begin{array}{l}\stackrel{ }{0} \\
\text { 言 }\end{array}$ \\
\hline $\begin{array}{l}\text { U obiteljskoj kući za jedno } \\
\text { kućanstvo }\end{array}$ & 16,7 & l & 1,7 & 14,3 & 5,9 & l & 10,7 \\
\hline $\begin{array}{l}\text { U obiteljskoj kući za jedno } \\
\text { kućanstvo s roditeljima }\end{array}$ & 25,0 & 20,0 & 37,3 & 2,9 & 29,4 & l & 13,3 \\
\hline U stanu u obiteljskoj kući & I & l & 5,1 & 20,6 & 5,9 & l & 14,8 \\
\hline $\begin{array}{l}\text { U stanu u obiteljskoj kući s } \\
\text { roditeljima }\end{array}$ & l & l & 15,3 & 2,3 & 5,9 & 50,0 & 5,6 \\
\hline U stanu u stambenoj zgradi & 58,3 & 40,0 & 15,3 & 54,3 & 17,6 & l & 43,0 \\
\hline $\begin{array}{l}\text { U stanu u stambenoj zgradi s } \\
\text { roditeljima }\end{array}$ & l & 40,0 & 25,3 & 4,6 & 35,3 & l & 11,5 \\
\hline Drugdje (npr. hotel, motel i sl.) & 1 & I & I & 1,1 & I & 50,0 & 1,1 \\
\hline Ukupno & 100 & 100 & 100 & 100 & 100 & 100 & 100 \\
\hline Broj kućanstava & 12 & 5 & 59 & 175 & 17 & 2 & 270 \\
\hline Pogreška uzorka (+/-) & 18,2 & 16,3 & 15,5 & 25,3 & 9,1 & 17,6 & 6,0 \\
\hline
\end{tabular}

18 Ovdje se može govoriti o populaciji mladih koji kasno izlaze iz roditeljskog doma, a po čemu je $\mathrm{Hr}$ vatska pri samom vrhu EU-a jer u prosjeku izlaze s 32 godine. Vidi: Eurostat, 2018. 


\section{Razina kvalitete stanovanja}

U ovom radu fokusirali smo se na nekoliko objektivnih (broj soba, veličinu stana i troškove najma) i subjektivnih (zadovoljstvo kvalitetom i sigurnošću stanovanja; zadovoljstvo okolišem i infrastrukturom u susjedstvu) obilježja kvalitete stanovanja za mjerenje utjecaja ove socijalne inovacije na dobrobit najmoprimaca (tablica 2). ${ }^{19}$ Opća procjena kvalitete prijašnjeg stanovanja mjerena je na skali s rasponom vrijednosti odgovora od 1 (uopće nisam zadovoljan/na) do 5 (u potpunosti sam zadovoljan/na). Zadovoljstvo okolišno-infrastrukturnim faktorima prijašnjeg stanovanja mjereno je kao kompozitna mjera odgovora na šest pitanja (sigurnost, kvaliteta zelenih površina ili parkova, čistoća okoliša, dostupnost javnog prijevoza, dostupnost telekomunikacijskih usluga, kvaliteta ulica) iz upitnika, kojima se procjenjivao stupanj zadovoljstva na istovjetnoj skali od 5 stupnjeva.

Tablica 2.

Rezultati usporedbe uvjeta stanovanja između prijašnjeg i sadašnjeg stambenog prostora

\begin{tabular}{|c|c|c|c|c|c|c|}
\hline Obilježje & $\begin{array}{l}\text { Stambeni } \\
\text { prostor }\end{array}$ & $\mathrm{N}$ & M & SD & $\mathbf{t}$ & $\mathbf{P}$ \\
\hline \multirow{2}{*}{ Broj prostorija } & Prije & 269 & 2,13 & 96 & \multirow{2}{*}{$-13,72$} & \multirow{2}{*}{, 000} \\
\hline & Sada & 269 & 3,11 &, 80 & & \\
\hline \multirow{2}{*}{ Ukupna površina u $\mathrm{m}^{2}$} & Prije & 267 & 57,75 & 26,33 & \multirow{2}{*}{$-14,390$} & \multirow{2}{*}{, 000} \\
\hline & Sada & 267 & 85,38 & 17,26 & & \\
\hline \multirow{2}{*}{$\begin{array}{l}\text { Iznos najma bez režijskih } \\
\text { troškova }\end{array}$} & Prije & 182 & 1625,31 & 518,70 & \multirow{2}{*}{$-1,964$} & \multirow{2}{*}{, 051} \\
\hline & Sada & 182 & 1700,65 & 246,20 & & \\
\hline \multirow{2}{*}{$\begin{array}{l}\text { Procjena kvalitete prijašnjeg } \\
\text { stanovanja }\end{array}$} & Prije & 268 & 5,67 & 2,16 & \multirow{2}{*}{$-9,740$} & \multirow{2}{*}{, 000} \\
\hline & Sada & 268 & 7,42 & 1,87 & & \\
\hline \multirow{2}{*}{$\begin{array}{l}\text { Zadovoljstvo okolišno- } \\
\text { infrastrukturnim faktorima }\end{array}$} & Prije & 262 & 23,15 & 4,63 & \multirow{2}{*}{,- 810} & \multirow{2}{*}{,418 } \\
\hline & Sada & 262 & 23,47 & 4,29 & & \\
\hline
\end{tabular}

Rezultati su pokazali da je broj soba bio veći u stanovima u kojima su sudionici istraživanja živjeli u tom trenutku $(\mathrm{t}=-13,72 ; \mathrm{p}<0,05)$. Prethodno, kućanstva su uglavnom živjela u dvosobnim stanovima (41,9\%), dok je ih više od četvrtine $(26,3 \%)$ živjelo u jednosobnim stanovima. Veličina stanova u kojima su u tom trenutku živjeli, mjereno $\mathrm{u} \mathrm{m}^{2}$, u prosjeku je bila veća nego prije $(\mathrm{t}=-14,390 ; \mathrm{p}<0,05)$, pa su stanari živjeli u većim stanovima. U vrijeme istraživanja većina ispitanika živjela je u trosobnim $(38,5 \%)$ i četverosobnim $(31,1 \%)$ stanovima. Prethodno, 31,9\% kućanstava živjelo je u stanovima do $45 \mathrm{~m}^{2}$ i samo $7,4 \%$ u stanovima preko $90 \mathrm{~m}^{2}$. U vrijeme istraživanja nijedna obitelj nije živjela u stanu do $40 \mathrm{~m}^{2}$, dok je $43,4 \%$ živjelo u stanovima većim

19 Razlika između prethodnih i trenutnih uvjeta stanovanja, uz pomoć različitih indikatora kvalitete stanovanja, analizirana je upotrebom t-testa za zavisne uzorke. 
od $90 \mathrm{~m}^{2} \cdot{ }^{20}$ Rezultati istraživanja pokazali su da su standard stanovanja i kvaliteta života u ovom naselju bili mnogo bolji u odnosu na prosječni stambeni rezultat baziran na rezultatima ranijeg istraživanja iz procjene stambenih potreba u Gradu Zagrebu (Bežovan, 2012.).

Razlike u troškovima najma između prijašnjeg i sadašnjeg stanovanja nisu se pokazale statistički značajnima $(t=1,964 ; p>0,05)$. Uvjetno rečeno, u segmentu financijske inovativnosti socijalnog predznaka, odnosno priuštivosti, program se nije pokazao inovativnim, iako su troškovi najma u prosjeku tek neznatno viši (75 HRK) zbog povećanog broja soba i veličine stana. Štoviše, za manje stanove stanari su u ranijem statusu plaćali relativno visoke iznose najamnine. Ipak, malen broj otkazanih ugovora u vrijeme istraživanja upućuje na činjenicu da su korisnici javno najamnog stanovanja smatrali najamninu priuštivom. ${ }^{21}$

Rezultati su pokazali da su ispitanici u vrijeme istraživanja procjenjivali razinu trenutne kvalitete stanovanja višom $(\mathrm{t}=-9,740 ; \mathrm{p}<0,05)$, dokle nije postojala razlika u stupnju zadovoljstva okolišno-infrastrukturnim faktorima ( $t=-, 810 ; \mathrm{p}>0,05)$. Zadovoljstvo okolišno-infrastrukturnim faktorima u novom stambenom naselju bilo je na približno jednakoj razini kao u naseljima gdje su ispitanici prije živjeli. To se može pripisati činjenici da je socijalna infrastruktura ovog stambenog naselja bila u procesu gradnje dok je istodobno kriza stopirala investicije u planirane objekte.

Rezultati mjerenja stupnja zadovoljstva određenim okolišno-infrastrukturnim indikatorima između prethodnog i trenutnog stanovanja (tablica 3) ukazivali su na statistički značajne razlike u korist sadašnjeg stanja, odnosno viši stupanj zadovoljstva kvalitetom zelenih površina ili parkova $(\mathrm{t}=-2,094 ; \mathrm{p}<0,05)$ i posebice osjećaja privatnosti $(\mathrm{t}=-$ 9,588; $\mathrm{p}<0,05)$ trenutnog stanovanja, dok su stanari ipak bili zadovoljniji sigurnošću $(\mathrm{t}=2,212 ; \mathrm{p}<0,05)$ i čistoćom okoliša $(\mathrm{t}=2,572 ; \mathrm{p}<0,05)$ u prethodnom stanovanju.

\footnotetext{
${ }^{20}$ Uvidom u strukturu i veličinu stanova u naselju Novi Jelkovec zaključuje se da one ne odgovaraju stambenim potrebama. Štoviše, udio jednosobnih stanova prikladnih za samce vrlo je malen, dok je udio stanova većih od $100 \mathrm{~m} 2$ stvorio problem njihove prodaje i najma. Gradski službenici u tome vide ključni problem što se tiče učinkovitosti ovog projekta.

21 Najpoznatija mjera priuštivosti, odnosno „cjenovne pristupačnosti“ stanovanja zasigurno je stopa (pre) opterećenosti troškom stanovanja (engl. housing cost overburden rate), koja se odnosi na udio stanovništva koje stanuje u kućanstvima gdje se $40 \%$ ili više ekvivalentnog raspoloživog dohotka troši na stanovanje. U troškove stanovanja uključeni su podjednako režijski i troškovi najma, odnosno (mogućeg) stambeno-kreditnog duga. Vidi detaljnije na: Eurostat, 2019. Međutim, zbog nedostatka pouzdanih podataka o ekvivalentnom dohotku javno najamnih kućanstva i visini režijskih troškova, mjera nije korištena u ovom radu.
} 
Tablica 3.

Rezultati usporedbe stupnja zadovoljstva pojedinim okolišno-infrastrukturnim činiteljima između prijašnjeg i sadašnjeg stambenog prostora

\begin{tabular}{|c|c|c|c|c|c|c|}
\hline Obilježje & $\begin{array}{l}\text { Stambeni } \\
\text { prostor }\end{array}$ & N & M & SD & $\mathbf{t}$ & $\mathbf{P}$ \\
\hline \multirow{2}{*}{$\begin{array}{l}\text { Sigurnost u prijašnjem stambenom } \\
\text { prostoru }\end{array}$} & Prije & 270 & 3,56 & 1,29 & \multirow{2}{*}{2,212} & \multirow{2}{*}{, 028} \\
\hline & Sada & 270 & 3,33 & 1,26 & & \\
\hline \multirow{2}{*}{$\begin{array}{l}\text { Kvaliteta zelenih površina ili parkova } \\
\text { u prijašnjem stambenom prostoru }\end{array}$} & Prije & 270 & 3,69 & 1,31 & \multirow{2}{*}{$-2,094$} & \multirow{2}{*}{, 037} \\
\hline & Sada & 270 & 3,93 & 1,11 & & \\
\hline \multirow{2}{*}{$\begin{array}{l}\text { Čistoća okoliša u prijašnjem } \\
\text { stambenom prostoru }\end{array}$} & Prije & 270 & 3,69 & 1,06 & \multirow{2}{*}{2,572} & \multirow{2}{*}{, 011} \\
\hline & Sada & 270 & 3,43 & 1,29 & & \\
\hline \multirow{2}{*}{ Osjećaj privatnosti } & Prije & 270 & 3,38 & 1,36 & \multirow{2}{*}{$-9,588$} & \multirow{2}{*}{, 000} \\
\hline & Sada & 270 & 4,39 & ,97 & & \\
\hline
\end{tabular}

Pojedinci su uselili u novo stambeno naselje na rubu grada i razumljivo je da su to mjesto smatrali nesigurnijim. Iz ranijeg istraživanja vidljivo je da sigurnost nije bio ozbiljan problem u Gradu Zagrebu (Bežovan i Rimac, 2008.). Ispitanici su u vrijeme istraživanja bili zadovoljniji kvalitetom zelenih površina i parkova u odnosu na prethodno mjesto stanovanja, iako je dokumentirano da su zelene površine i parkovi inače kritični nedostaci novih stambenih naselja u Zagrebu (Svirčić Gotovac, 2012.:20-21). Situacija s čistoćom okoliša bila je bolja u prethodnom mjestu stanovanja.

Dom kao sklonište jest mjesto privatnosti i u slučajevima kada obitelj nije u stanju osigurati privatnost, članovi obitelji mogu biti frustrirani. Socijalna stabilnost obitelji povezana je s veličinom, strukturom i prirodom životnog prostora. Rezultati analize indikatora privatnosti ukazali su na poboljšanje osjećaja privatnosti kod stanara, što je posebice relevantno za kućanstva čiji su članovi prethodno živjeli s roditeljima i širom obitelji u obiteljskim kućama. Stoga predstavljeni rezultati pružaju dodatan argument za opće poboljšanje kvalitete stanovanja u novim stanovima.

Razlike u odnosu na zadovoljstvo okolišno-infrastrukturnim faktorima postojale su unutar naselja, i prikazane su usporedbom četiriju stambenih blokova u naselju (A, B, C i D). Rezultati analize varijance (ANOVA) pokazale su statistički značajne razlike u stupnju zadovoljstva okolišno-infrastrukturnim faktorima sukladno stambenom bloku u kojem se ispitanici nalaze $(\mathrm{F}=8,72 ; \mathrm{p}<0,05)$. Post-hoc analize provedene Scheffeovim testom pokazale su da su stanari iz bloka C i D bili zadovoljniji od stanara iz bloka 
A i da su stanari iz bloka D bili zadovoljniji od stanara iz bloka B. Blokovi A i D gušće su građeni, s manje zelenih površina i javnih prostora. Veća gustoća populacije u tim blokovima činila je pojedince nezadovoljnijima (tablica 4).

Tablica 4.

Razlike u stupnju zadovoljstva okolišno-infrastrukturnim faktorima prema bloku stanovanja

\begin{tabular}{|c|c|c|c|c|c|c|c|}
\hline Obilježje & Blok & $\mathrm{N}$ & M & SD & $\mathbf{F}$ & $p$ & $\begin{array}{l}\text { Post-hoc } \\
\text { (Scheffe) }\end{array}$ \\
\hline \multirow{4}{*}{$\begin{array}{l}\text { Zadovoljstvo okolišno- } \\
\text { infrastrukturnim } \\
\text { faktorima }\end{array}$} & A & 98 & 22,38 & 4,63 & \multirow{4}{*}{8,72} & \multirow{4}{*}{,000 } & \multirow{4}{*}{$\begin{array}{l}A-C^{* *} \\
A-D^{* *} \\
B-D^{* *}\end{array}$} \\
\hline & $B$ & 52 & 22,32 & 4,64 & & & \\
\hline & C & 23 & 25,21 & 2,76 & & & \\
\hline & D & 91 & 24,92 & 3,43 & & & \\
\hline
\end{tabular}

Prema stupnju zadovoljstva određenim okolišno-infrastrukturnim faktorima, rezultati ANOVA-e (tablica 5) pokazali su da ne postoje razlike u razini zadovoljstva sigurnošću u stambenom naselju među stanarima različitih blokova $(F=, 889 ; p>0,05)$. Prema razini zadovoljstva kvalitetom zelenih površina ili parkova, razlika je bila vidljiva između stanara različitih stambenih blokova $(\mathrm{F}=9,487 ; \mathrm{p}<0,05)$. Post-hoc analize provedene Scheffeovim testom pokazale su da su stanari iz blokova C i D zadovoljniji kvalitetom zelenih površina od stanara iz bloka A. Rezultati su također ukazali na varijaciju u razini zadovoljstva čistoćom okoliša u odnosu na stambene blokove $(F=25,837 ; p<0,05)$, dok su post-hoc analize provedene Scheffeovim testom pokazale da su stanari iz blokova $\mathrm{C}$ i D bili zadovoljniji čistoćom okoliša od stanara iz blokova A i B.

Tablica 5.

Razlike u stupnju zadovoljstva pojedinim okolišno-infrastrukturnim faktorima prema bloku stanovanja

\begin{tabular}{|c|c|c|c|c|c|c|c|}
\hline $\begin{array}{l}\text { Okolišno- } \\
\text { infrastrukturni } \\
\text { faktori }\end{array}$ & Blok & N & M & SD & $\mathbf{F}$ & $\mathbf{P}$ & $\begin{array}{l}\text { Post -hoc } \\
\text { (Scheffe) }\end{array}$ \\
\hline \multirow{4}{*}{ Sigurnost } & A & 102 & 3,32 & 1,299 & \multirow{4}{*}{,889 } & \multirow{4}{*}{,447 } & \\
\hline & B & 53 & 3,09 & 1,244 & & & \\
\hline & C & 23 & 3,48 & ,994 & & & \\
\hline & D & 92 & 3,42 & 1,294 & & & \\
\hline \multirow{4}{*}{$\begin{array}{l}\text { Kvaliteta zelenih } \\
\text { površina ili parkova }\end{array}$} & A & 102 & 3,55 & 1,191 & \multirow{4}{*}{9,478} & \multirow{4}{*}{, 000} & \multirow{4}{*}{$\begin{array}{l}A-C^{* *} \\
A-D^{* *}\end{array}$} \\
\hline & B & 53 & 3,81 & 1,287 & & & \\
\hline & $\mathrm{C}$ & 23 & 4,26 & 810 & & & \\
\hline & $\mathrm{D}$ & 92 & 4,33 &, 813 & & & \\
\hline \multirow{4}{*}{ Čistoća okoliša } & A & 102 & 2,87 & 1,295 & \multirow{4}{*}{25,837} & \multirow{4}{*}{, 000} & $A-C^{* *}$ \\
\hline & B & 53 & 2,96 & 1,358 & & & $A-D^{* *}$ \\
\hline & C & 23 & 4,13 &, 626 & & & $\mathrm{~B}-\mathrm{C}^{* *}$ \\
\hline & D & 92 & 4,14 & ,897 & & & $B-D^{* *}$ \\
\hline
\end{tabular}




\section{Suočavanje s krizom}

Dio problema s kojim se ova populacija suočavala, kao što je prethodno spomenuto, troškovi su stanovanja. Velik udio proračuna kućanstava s niskim dohotkom - pogotovo ako su unajmljivali stanove na tržištu - otpadao je na troškove stanovanja, dok su druge potrebe redovito ostajale nepodmirene. Ta su kućanstva u vrijeme istraživanja još uvijek koristila razne strategije suočavanja s visokim troškovima stanovanja. Distribucija odgovora za načine rješavanja problema visokih troškova kućanstva (tablica 6) pokazala je da su kućanstva uglavnom ograničavala potrošnju energije $(77,2 \%)$, ograničavala troškove za druge potrebe $(77,5 \%)$, uzimala kredite $(67,9 \%)$ i da su članovi radili prekovremeno $(46,3 \%)$.

Tablica 6.

Distribucija odgovora za načine rješavanja problema visokih troškova kućanstva

\begin{tabular}{|l|c|c|c|c|}
\hline \multirow{2}{*}{ Načini rješavanja } & \multicolumn{2}{|c|}{ Da } & \multicolumn{2}{c|}{ Ne } \\
\cline { 2 - 5 } & f & $\%$ & 61 & 22,8 \\
\hline Ograničavamo potrošnju energije & 206 & 77,2 & 60 & 22,5 \\
\hline Ograničavamo izdatke za druge potrebe & 207 & 77,5 & 144 & 53,7 \\
\hline Radimo prekovremeno & 124 & 46,3 & 200 & 76,3 \\
\hline Trošimo ušteđevinu & 62 & 23,7 & 248 & 93,6 \\
\hline Prodajemo imovinu & 17 & 6,4 & 266 & 100,0 \\
\hline Iznajmljujemo dio stana & 0 & 0,0 & 241 & 90,6 \\
\hline Tražimo jeftiniji stan & 25 & 9,4 & 209 & 78,3 \\
\hline Financijska pomoć rodbine i prijatelja & 58 & 21,7 & 243 & 91,4 \\
\hline Tražimo subvenciju najamnine i troškova & 23 & 8,6 & 174 & 65,2 \\
\hline Radimo dodatne poslove & 93 & 34,8 & 86 & 32,1 \\
\hline Zaduživanje u banci & 182 & 67,9 & 207 & 94,1 \\
\hline Drugačije & 13 & 5,9 & & \\
\hline
\end{tabular}

Kako bi bolje razumjeli položaj različitih obitelji kao korisnika ove inovacije testirali smo dvije dodatne hipoteze korištenjem regresijske analize izabranih varijabli.

Hipoteza 2: Najmoprimci nižeg obrazovanja i nižih prihoda koji stanuju u većim stanovima iskazuju niži stupanj zadovoljstva uvjetima i troškovima stanovanja.

Hipoteza 3: Najmoprimci koji su ranije bili podstanari u manjim stanovima iskazuju viši stupanj zadovoljstva uvjetima stanovanja.

Rezultati zasebnih regresijskih analiza kojima se provjeravala predikcija različitih aspekata zadovoljstva kvalitetom stanovanja na osnovu skupa prediktora (stupanj obrazovanja, visina dohotka, veličina stana, prijašnja veličina stana te prijašnji pravni status stanovanja) predočeni su u nastavku (tablica 7). 
Tablica 7.

Rezultati regresijskih analiza

\begin{tabular}{|l|c|c|c|c|}
\hline Prediktori & $\boldsymbol{\beta}$ & $\mathbf{R}$ & $\mathbf{R}^{\mathbf{2}}$ & $\mathbf{F}$ \\
\hline Zadovoljstvo opremljenošću stana & & & & \\
\hline Stupanj obrazovanja & $0,141^{*}$ & 0,188 & 0,035 & 2,879 \\
\hline Zadovoljstvo veličinom stana & & & & \\
\hline Veličina stana & $0,199^{*}$ & 0,251 & 0,063 & 5,288 \\
\hline Prijašnji pravni status stanovanja & $0,144^{*}$ & 0,267 & 0,071 & \multirow{2}{*}{9,231} \\
\hline Prijašnja veličina stana & $0,227^{*}$ & & & \\
\hline Zadovoljstvo troškovima stanovanja & & & & 6,557 \\
\hline Visina dohotka & $-0,274^{*}$ & 0,265 & 0,07 & \\
\hline Zadovoljstvo okolišnim faktorima & & & & 4,625 \\
\hline Prijašnji pravni status stanovanja & $-0,189^{*}$ & 0,192 & 0,037 & \\
\hline Zadovoljstvo dostupnošću medicinskih $\mathbf{i}$ komercijalnih usluga & & & & \\
\hline Prijašnji pravni status stanovanja & $-0,153^{*}$ & 0,171 & 0,029 & 3,616 \\
\hline Zadovoljstvo dostupnošću usluga za djecu & & & & \\
\hline Prijašnji pravni status stanovanja & $0,15^{*}$ & 0,180 & 0,032 & 4,021 \\
\hline Zadovoljstvo dostupnošću kulturnih i uslužnih djelatnosti & & & & \\
\hline Prijašnji pravni status stanovanja & $-0,181^{*}$ & 0,205 & 0,042 & 5,267 \\
\hline
\end{tabular}

${ }^{*} p<0.05$.

Slijedom pojavljivanja, od vrha prema dnu tablice, rezultati se interpretiraju na sljedeći način.

Rezultati regresijske analize stupnja zadovoljstva opremljenošću stana pokazuju da se stupanj obrazovanja potvrdio kao signifikantan prediktor $(\beta=0,141)$ važeći za $3,5 \%$ kriterijske varijance $(\mathrm{R}=0,188 ; \mathrm{F}=2,87 ; p<0,05)$.

Rezultati regresijske analize stupnja zadovoljstva veličinom stana pokazuju da se veličina stana potvrdila kao signifikantan prediktor $(\beta=0,199)$ važeći za $6,3 \%$ kriterijske varijance $(R=0,251 ; F=2,28 ; p<0,05)$. Također, rezultati pokazuju da su se prijašnji pravni status stanovanja $(\beta=0,141)$ i veličina stana $(\beta=0,227)$ potvrdili kao signifikantni prediktori važeći za $7,1 \%$ kriterijske varijance $(\mathrm{R}=0,267 ; \mathrm{F}=9,23 ; p<0,05)$.

Rezultati regresijske analize stupnja zadovoljstva troškovima stanovanja pokazuju da se visina dohotka potvrdila kao signifikantan prediktor $(\beta=-0,274)$ važeći za $7 \%$ kriterijske varijance $(\mathrm{R}=0,265 ; \mathrm{F}=6,55 ; p<0,05)$.

Rezultati regresijske analize stupnja zadovoljstva okolišnim faktorima pokazuju da se prijašnji pravni status stanovanja potvrdio kao signifikantan prediktor $(\beta=-0,189)$ važeći za 3,7\% kriterijske varijance $(\mathrm{R}=0,192 ; \mathrm{F}=4,62 ; p<0,05)$. 
Rezultati regresijske analize stupnja zadovoljstva dostupnošću medicinskih i komercijalnih usluga pokazuju da se prijašnji pravni status stanovanja potvrdio kao signifikantan prediktor $(\beta=-0,153)$ važeći za $2,9 \%$ kriterijske varijance $(R=0,171 ; F=3,61$; $p<0,05)$.

Rezultati regresijske analize stupnja zadovoljstva dostupnošću usluga za djecu pokazuju da se prijašnji pravni status stanovanja potvrdio kao signifikantan prediktor $(\beta=0,15)$ važeći za 3,2\% kriterijske varijance $(\mathrm{R}=0,180 ; \mathrm{F}=4,02 ; p<0,05)$.

Rezultati regresijske analize stupnja zadovoljstva dostupnošću kulturnih i uslužnih djelatnosti pokazuju da se prijašnji pravni status stanovanja potvrdio kao signifikantan prediktor $(\beta=-0,181)$ važeći za $4,2 \%$ kriterijske varijance $(R=0,205 ; F=5,26 ; p<0,05)$.

Druga je hipoteza djelomično potvrđena te stanari s nižim mjesečnim prihodima procjenjuju troškove stanovanja višima. Ta bi činjenica podrazumijevala postojanje programa subvencija troškova stanovanja za tu populaciju. Također je djelomično potvrđena i treća hipoteza jer su bivši podstanari bili zadovoljniji veličinom stanova, odnosno uvjetima stanovanja. Nadalje, bili su zadovoljniji i objektima te okolišem u ovom naselju.

\section{Zaključak}

Model stambenog zbrinjavanja stjecanjem stana u vlasništvo dominantna je činjenica postsocijalističkih europskih država. Stoga su u tim državama, a tako i u Hrvatskoj, prijelazni modeli i inovacije u stambenim sektorima rijetki i teško održivi (Hegedüs, Lux i Teller, 2013.). Istraživana inovacija javno najamnih stanova u zagrebačkom naselju Novi Jelkovec primjer je nove usluge koja relativno bolje podmiruje stambene potrebe te ima šire učinke, koji joj daju obrise socijalnog ulaganja. Program ovog tipa sačinjen je sa svrhom podmirivanja potreba mladih obitelji s djecom koje nemaju pravo na dodjelu socijalnog stana, a ne mogu si priuštiti stambene kredite za kupnju odgovarajućih stanova. U središnjem dijelu rada prikazani su rezultati ankete o utjecaju programa javnog najamnog stanovanja na kvalitetu života stanara, koja se bazirala na objektivnim i subjektivnim varijablama kvalitete stanovanja.

Obuhvaćanjem ciljanih skupina koje su ranjive na stambenom tržištu, ovaj je inovativni program u vrijeme istraživanja ispunio važan dio svoje misije. Kućanstva izložena nekontroliranom i nestabilnom stambenom tržištu privatnog najamnog sektora i oni koji žive s roditeljima postali su najmoprimci priuštivog im javno najamnog stanovanja.

Kvaliteta stanovanja u javno najamnom stanovanju vidljivo se poboljšala u odnosu na prethodno stanovanje najmoprimaca. Kućanstva su u trenutku istraživanja živjela 
u novim, dovoljno velikim stanovima, sa stabilnim ugovorima te su mogla uspješno kontrolirati vlastite živote i planirati budućnost. Kako je u vrijeme istraživanja u naselju socijalna infrastruktura bila u procesu gradnje, može se zaključiti da je stupanj zadovoljstva kvalitetom stanovanja u tom smislu bio djelomično umanjen. K tome, unutar samog naselja kvaliteta se stanovanja razlikovala glede zelenih površina, parkova i čistoće okoliša. Tijekom krize kućanstvima s nižim dohotkom najamnine i troškovi stanovanja bili su teret za kućni proračun. Suočena s tim izazovima dovijala su se na različite načine, ograničavanjem troškova za podmirenje drugih potreba, ograničavanjem potrošnje energije, uzimanjem kredita te zarađivanjem dodatnim radom.

Korisnici programa nisu bili u poziciji da aktivno sudjeluju u redizajnu programa i njegovom dodatnom inoviranju, ali bi njihova (ovdje dokumentirana) iskustva mogla biti korisna za navedene namjere i eventualno unaprjeđenje ove inovacije u budućnosti. Prema tvrdnjama intervjuiranih službenih osoba u Gradu Zagrebu, a što se tiče unutarnje organizacije i načina rada, inovacija je bila stabilna i tek je malen broj stanara raskinuo ugovore i napustio stanove. Očigledno postoji prostor za interakciju ove inovacije s lokalnim socijalnim sustavom. Javni najmoprimci načelno su zauzetiji i društveno odgovorniji građani. Ova je inovacija dobila „pravo građanstva“ pošto su je naknadno neki drugi hrvatski gradovi u svojim inačicama, primjerice Varaždin, implementirali u vlastitim okolnostima. Kao ishod, ova je inovacija učinila priuštivo stanovanje dostupnim za ranjive socijalne skupine. Dobrobit i kvaliteta stanovanja najmoprimaca poboljšani su. Inovacija je odgovorila na životne potrebe korisnika te im omogućila nesputano planiranje budućnosti, što se smatra učinkom ove inovacije. 


\section{Literatura}

1. Andreotti, A.; Mingione, E. and Polizzi, E. (2012). Local Welfare Systems: A Challenge for Social Cohesion. Urban Studies, 49 (9): 1925-1940. DOI: 10.1177/0042098012444884

2. Ball, M. (1983). Housing Policy and Economic Power: The Political Economy of Owner Occupation. London: Methuen.

3. Bežovan, G. (2005). Procjena standarda stanovanja u Zagrebu kao razvojnog resursa. Revija za socijalnu politiku, 12 (1): 23-44. DOI: 10.3935/rsp.v12i1.19

4. Bežovan, G. (2012). Procjena stambenih potreba u Hrvatskoj. Zagreb: CERANEO.

5. Bežovan, G. (2019). Stambeno zbrinjavanje kao jedan od ključnih čimbenika demografske obnove, VII. Nacionalni kongres Hrvatskog sociološkog društva - Socijalna kohezija u drusttvu polarizacije, konflikata i nejednakosti, Zagreb, 11-12. travnja 2019. http://hsd.hr/wp-content/uploads/sites/598/2019/04/Socijalna kohezija_2019.pdf. (Pregledano 6. srpnja 2019.)

6. Bežovan, G. i Rimac, I. (2008). Kvaliteta života i rad Gradske uprave u Zagrebu. Zagreb: CERANEO.

7. Bežovan, G.; Matančević, J. and Baturina, D. (2012). City Report: Zagreb. WILCO Publication, No. 32. http://www.wilcoproject.eu/wordpress/wp-content/uploads/WILCO_WP3_Zagreb_321.pdf. (Pregledano 19. srpnja 2018.)

8. Bežovan, G.; Matančević, J. i Baturina, D. (2016). Socijalne inovacije kao doprinos jačanju socijalne kohezije i ublažavanju socijalne krize u europskim urbanim socijalnim programima. Revija za socijalnu politiku, 23 (1): 61-80.

9. BEPA (2010). Empowering people, driving change: Social innovation in the European Union. Bruxelles: European Commission.

10. Blyth, M. (2013). Austerity. The History of a Dangerous Idea. Oxford: Oxford University Press.

11. Brandsen, T.; Cattacin, S.; Evers, A.; Zimmer, A. (2016). Social innovations in the urban context. New York: Springer International Publishing.

12. Costa, G.; Bežovan, G.; Plavarini, P.; Brandsen, T. (2014). Urban Housing systems in times of crisis, in: Ranci, C.; Brandsen T. and Sabatinelli, S. (Eds.). Social vulnerability in European cities: The role of welfare in times of crisis. London: Palgrave Macmillan: 160-186.

13. Czischke, D. (2013). Social Innovation in Housing: Learning from practice across Europe. Discussion paper commissioned by the Chartered Institute of Housing on behalf of the Butler Bursary. http://www.cih.org/resources/PDF/Membership/Social\%20Innovation\%20in \%20Housing\%20-\%20Darinka $\% 20$ Czischke\%20Final\%20report\%20and\%20appendix\%20Dec\%202013.pdf. (Pregledano 8. lipnja 2017.)

14. Državni zavod za statistiku (1991). Popis stanovništva, kućanstava i stanova. Zagreb: DZS.

15. Državni zavod za statistiku (2011). Popis stanovništva, kućanstava i stanova. Zagreb: DZS. 
16. Elliot, J. A. (2006). An Introduction to Sustainable Development. Third Edition. London and New York: Routledge.

17. Elsinga, M. and Mandič, S. (2010). Housing as a Piece in the Old-Age Puzzle. The role of housing equity in old-age security in eight countries. Teorija in Praksa, 47 (5): 940-959.

18. Esping-Andersen, G. (1990). The Three Worlds of Welfare Capitalism. Princeton: Princeton University Press.

19. European Commission (2010). Study on Housing Exclusion: Welfare Policies, Housing Provision and Labour Markets. https:/www.york.ac.uk/media/chp/ documents/2010/Study\%20on\%20Housing\%20Exclusion.pdf. (Pregledano 1. rujna 2017.)

20. Europska komisija (2013). Prema socijalnom ulaganju za rast i koheziju uključujući i provedbu Europskog socijalnog fonda za razdoblje 2014. - 2020. Revija za socijalnu politiku, 20 (2): 167-190.

21. Eurostat (2018). Bye bye parents: when do young Europeans flee the nest?. https://ec.europa.eu/eurostat/web/products-eurostat-news/-/EDN-20180515-1. (Pregledano 8. srpnja 2018.)

22. Eurostat (2019). Housing affordability. https://ec.europa.eu/eurostat/statisticsexplained/index.php?title=Housing_statistics\#Housing_affordability. (Pregledano 5. rujna 2019.)

23. Fenger, H. J. M. (2007). Welfare regimes in Central and Eastern Europe: Incorporating postcommunist countries in a welfare regime typology. Contemporary Issues and Ideas in Social Sciences, 3 (2): 1-30.

24. Ferrera, M. (1996). The „Southern Model“ of Welfare in Social Europe. Journal of European Social Policy, 6 (1): 17-37. DOI: 10.1177/095892879600600102

25. Garcia, M. and Haddock, S. V. (2016). Special issue: housing and community needs and social innovation responses in times of crisis. Journal of Housing and the Built Environment, 31 (3): 393-407. DOI: 10.1007/s10901-015-9466-1

26. Harloe, M. (1995). The People's Home? Social Rented Housing in Europe \& America. Oxford and Cambridge: Blackwell Press.

27. Hegedüs, J. (2013). A Transformation of the Social Housing Sector in Eastern Europe: A Conceptual Framework, in: Hegedüs, J.; Lux, M. and Teller, N. (Eds.). Social Housing in Transitional Countries. New York: Routledge: 3-30.

28. Hegedüs, J.; Horváth, V. and Somogyi, E. (2017). Affordable Housing in Central and Eastern Europe: Identifying and Overcoming Constrains in New Member States. Budapest: Metropolitan Research Institute.

29. Hegedüs, J.; Lux, M. and Sunega, P. (2011). Decline and Depression: the Impact of the Global Economic Crisis on Housing Markets in Two Post-Socialist States. Journal of Housing and the Built Environment, 26: 315-33. DOI: 10.1007/s10901-011-9228-7

30. Hegedüs, J.; Lux, M. and Teller, N. (2013). Social Housing in Transitional Countries. New York: Routledge. 
31. Hegedüs, J.; Lux, M. and Horváth, V. (2018). Private Rental Housing in Transition Countries: An Alternative to Home Ownership? London: Palgrave-Macmillan.

32. Hemerijck, A. (2017). Social Investment and its Critics, in: Hemerijck, A. (Ed.). The Uses of Social investment. Oxford: Oxford University Press: 3-39.

33. Kearns, A. and Paddison, R. (2000). New Challenges for Urban Governance. Urban Studies, 37 (5-6): 845-850. DOI: 10.1080/00420980050011118

34. Lux, M. and Sunega, P. (2012). Labour Mobility and Housing: The Impact of Housing Tenure and Housing Affordability on Labour Migration in the Czech Republic. Urban Studies, 49 (3): 489-504. DOI: 10.1177/0042098011405693

35. Lux, M. and Sunega, P. (2013). New Social Housing Strategies in Post-Socialist States- Effectiveness, Efficiency and Sustainability, in: Hegedüs, J.; Lux, M. and Teller, N. (Eds.). Social Housing in Transitional Countries. New York: Routledge: 307-330.

36. Lux, M. (2019). Path dependence and housing systems in CEE - new challenges. Urban and Housing Systems under Pressure: Varieties of Responses, MRI Conference, Budapest, 27-29. rujna 2019. https://mri.hu/en/wp-content/uploads/ sites/2/2019/10/Martin-Lux.pdf. (Pregledano 10. listopada 2019.)

37. Mullins, D. and Moore, T. (2018). Self-organised and civil society participation in housing provision. International Journal of Housing Policy, 18 (1): 1-14. DOI: 10.1080/19491247.2018.1422320

38. Phills, J. A.; Deiglmeier, K. and Miller, D. T. (2008). Rediscovering Social Innovation. Stanford Social Innovation Review, 6: 34-43.

39. Ranci, C.; Brandsen, T. and Sabatinelli, S. (2014). Social Vulnerability in European Cities: The Role of Local Welfare in Times of Crisis. London: Palgrave Macmillan.

40. Službeni glasnik Grada Zagreba, Odluka o najmu javno najamnih stanova, 7/2009, 22/2009 i 26/2014.

41. Službeni glasnik Grada Zagreba, Zaključak o visini najamnine za javno najamne stanove, $1 / 2014$.

42. Stephens, M.; Lux, M. and Sunega, P. (2015). Post-Socialist Housing Systems in Europe: Housing Welfare Regimes by Default?. Housing Studies, 30 (8): 12101234.

43. Svirčić Gotovac, A. (2006). The quality of living in the settlements network in Croatia. Sociologija sela, 44 (1): 105-126.

44. Svirčić Gotovac, A. (2012). Akteri društvenih promjena u prostoru (20072011), u: Svirčić Gotovac, A. i Zlatar, J. (Ur.). Akteri društvenih promjena u prostoru; transformacija prostora i kvalitete života u Hrvatskoj. Zagreb: Institut za društvena istraživanja: 13-27.

45. Svirčić Gotovac, A. i Zlatar, J. (2015). Novi Jelkovec ili Sopnica-Jelkovec kao primjer POS-ovog naselja, u: Svirčić Gotovac, A. i Zlatar, J. (Ur.). Kvaliteta života u novostambenim naseljima i lokacijama u zagrebačkoj mreži naselja. Zagreb: Institut za društvena istraživanja: 147-180. 